DOI: $10.31249 / \mathrm{rsm} / 2020.04 .09$

\title{
А.А. Кузицына
}

\section{США И КИТАЙ: КОГАА СОСТОИТСЯ “БИТВА ЗА АНКОРИАЖ"?}

Аннотация. Отношения между США и КНР, двумя мощчнейшими державами, в ХХІ в. в значительной степени формируют общую геополитическую картину мира и влияют на развитие всех других акторов международной жизни. Тем важнее исследовать наметившийся раскол между стратегическими партнерами, которые связаны друг с другом интенсивными экономическими, финансовыми, технологическими и гуманитарными отношениями. Основной мотив противостояния заключается в том, что США не готовы делить влияние с нарашиваюшим свою экономику Китаем. В Стратегии национальной безопасности США Китай наряду с Россией назван основным противником. Одним из ярких проявлений схватки за передельл сфер влияния стала развернувшаяся торговая война 2018-2019 г2., получившая поистине глобальные масштабы. В статье исследуются причины того, что отношения США и Китая могут в долгосрочной перспективе грозить обострением вплоть до военных действий. Выявлен ряд неразрешимых в рамках существующих форматов международного общения противоречий, особенно обостривщихся в период правления администрации Д. Трампа. При этом показано, как общее развитие ситуации может повлиять на то, что ни Пекин, ни Вашингтон не смогут избежать конфликта интересов без существенных потерь для своего статуса. В качестве иллюстрации того, что современный геополитический кризис был изначально заложен в конфигурацию отношений мировых гигантов, представлены прогнозы в произведениях массовой культуры США кония ХХ в., в которых сиенаристы предполагали осуществление сиенария «битвы за Анкоридж». В итоге делается вывод о том, что конфликт между США и Китаем имеет системный характер. Высказывается также прогноз о возможных временньі́х и ситуативных рамках приближающейся эскалаџии глобального конфликта.

Ключевые слова: Китай; США; торговая война; конфронтация.

Кузицына Анна Альбертовна - аспирант МГУ им. М.В. Ломоносова,

Россия, Москва. E-mail:akuzitsyna@mail.ru

Kuzitsyna A.A. The USA and China: When Will the «Battle for Anchorage» Take Place?

Abstract. In the 21st century, the relationship between the United States and China, the two most influential world powers, largely shapes the general geopolitical situation in 158 
the world and affects the development of all other international actors. That is why it is important to highlight the emergent sharp cleavage between the two largest world economies, linked by intensive economic, financial, technological and humanitarian contacts. The main motive for the confrontation on the American side is that the United States is unwilling to share its sphere of influence with China, while Beijing is steadfastly increasing its economic might. The US national security strategy labels China and Russia as major adversaries. One of the most vivid manifestations of remapping the world and spheres of influence was the trade war between the USA and China in 2018-2019, which became a global phenomenon. The article examines why the US-China relations might escalate into an all-out war in the long term. Identified is a number of unresolved contradictions within the existing formats of international communication, which have been exacerbated during D. Trump tenure. Also, the article shows the overall evolution of the situation in which neither Beijing nor Washington could avoid a conflict of interests without losing their current status. This might be illustrated by numerous predictions in the US mass culture about a coming «battle of for Anchorage». By way of conclusion, the author argues that the conflict between the USA and China is of a deep systemic nature and offers a prognosis on how it might escalate in the coming years.

Keywords: China; the USA; trade war; confrontation.

Kuzitsyna Anna Albertovna - Post-Graduate Student,

Lomonosov Moscow State University, Russia, Moscow.

E-mail: akuzitsyna@mail.ru

Одной из особенностей информационного общества становится анонсирование мировых потрясений через произведения литературы, сценарии компьютерных игр, видеоблоги и другие проявления массовой культуры. Так, в 1997 г. компания «Интерплей Продакшен» (Interplay Productions) в сценарии постапокалиптической игры «Fallout» представила войну, которая, по идее авторов, разразится между Китаем и США в 2066 г. Поводом для «конца света», согласно фантастическому сценарию, послужил спор двух держав за обладание нефтяными и газовыми месторождениями на Аляске. В результате локальная «битва за Анкоридж» привела к обмену ядерными, химическими и биологическими ударами между США и КНР.

Для исследователя представляет интерес тренд, который привел сценаристов к такому пророческому ви́дению будущего. Так, к моменту выхода «Fallout» в США наметился дефицит торговли с КНР, в 1996 г. составивший 20 млрд долл. США. В 2006 г. дефицит торговли с Китаем в Штатах достиг своего пика - 828 млрд долл. США. Под давлением США Китай с 2000 г. ежегодно повышал на 2-3\% курс юаня по отношению к доллару, что способствовало некоторому снижению дефицита в торговле в ценовом выражении. Однако в 2017 г. дефицит составил 375 млрд долл., а в 2018 г. вырос до 419 млрд долл. 
Основная причина дефицита торговли заключается в переносе производства США в КНР из-за стремления производителей удешевить продукцию в условиях жесткой конкуренции. Для Китая характерна низкая стоимость рабочей силы, удобная логистика, доступные ресурсы, почти полное отсутствие расходов на сохранение окружающей среды, высокая лояльность руководства страны к инвесторам, низкий курс юаня, частично привязанного к доллару. Что касается США, значительную долю ВВП (по разным оценкам, порядка $80 \%$ ) составляет сфера услуг. Количество рабочих мест, занятых непосредственно в производстве товаров в США, за период с 1998 по 2010 г. сократилось на $34 \%$, и есть все основания полагать, что большая часть этих мигрировавших рабочих мест из США переместилась в КНР. Американские компании должны резко сокращать производственные расходы или уходить с рынка, либо производители в США должны поддерживать такую администрацию Белого дома, которая будет устранять конкурентов нерыночными способами.

Поднебесная вынуждена поддерживать доллар, для чего Пекину приходится покупать казначейские обязательства Вашингтона. Китай является крупнейшим кредитором правительства США. На апрель 2019 г. долг США перед Китаем составил 1,1 трлн долл. Это 27\% всего долга США иностранным кредиторам.

В Вашингтоне зависимость от Пекина вызывает тревогу. Если Китай начнет продавать казначейские обязательства США или хотя бы прекратит их покупать, Штаты могут впасть в рецессию. Однако Китаю невыгодна рецессия в США, которая приведет к уменьшению покупательной способности потребителей, тратящих своих деньги на китайские товары. Таким образом, кредитор (КНР) более заинтересован в экономической стабильности должника (США), чем должник в устойчивости и стабильности кредитовавшего его партнера. Вашингтон выдвигает новые претензии к Пекину, обвиняя его и в нечестной игре с юанем, и в краже интеллектуальной собственности, и в установлении ограничений, вводимых для американских компаний на китайском рынке [Трамп заявил 2018].

Во время предвыборной гонки 2016 г. будущий президент Дональд Трамп неоднократно критиковал политику Демократической партии, допустившей дисбаланс в торговле с Китаем. Трамп обещал в случае своего избрания «разобраться с Китаем», и теперь угрозы превращаются в действия.

Открытое противостояние двух ведущих экономик началось в 2017 г., а дальше лишь набирало обороты. В январе 2018 г. США установили $30 \%$ пошлины на ввозимые солнечные батареи. Также обложены пошлинами, ввозимые в основном из КНР, стиральные машины. В марте 2018 г. США завершили расследование кражи интеллектуальной собственности Китаем. Введены торговые пошлины 10-25\% на ввозимые в Штаты сталь и алюминий. Китай ответил симметрично: введены 10-15\% пошлины на 128 американских 
наименований товаров. С марта по сентябрь 2018 г. каждая сторона обложила пошлинами более чем на 200 млрд долл. несколько тысяч наименований товаров. На каждое действие США китайские власти принимали зеркальные меры. Например, 23 августа 2018 г. США ввели 25\%-ные пошлины на те же 16 млрд долл. КНР сделали то же самое: ввели те же 25\%-ные пошлины на 16 млрд долл.

Любопытно, что на момент создания сценария игры «Фаллаут», в которой две державы воюют за месторождения на Аляске, Китай никак не был представлен в этом регионе. Однако спустя два десятилетия между КНР и США было достигнуто соглашение, по которому Вашингтон допустил Пекин к разработке газовых месторождений на Аляске за 46 млрд долл. списанных долгов [Трамп добился 2018]. Таким образом, в этой части предсказание уже сбылось, поскольку появилась еще одна площадка для возможных трений в будущем. Например, однажды в Вашингтоне могут вернуться к этому уже оплаченному Пекином соглашению и посчитать его недостаточно выгодным на фоне усложняющейся ситуации с углеводородами.

Разразившаяся торговая война не первая в отношениях двух стран, но впервые она приняла такой ожесточенный характер. Ярким всплеском конфликта стал арест в Канаде по запросу США финансового директора «Хуавей» (Huawei) Мэн Ванчжоу. Компания «Хуавей» является флагманом двух проектов Си Цзиньпина «Один пояс, один путь» и «Сделано в Китае $2025 »$. Арест дочери основателя компании, являющейся ее топ-менеджером, всколыхнул китайское общество, поскольку здесь была затронута не только экономика, но и национальная гордость. Несмотря на готовность к переговорам, продемонстрированную китайской стороной, США намеренно нагнетали обстановку. В разгар полемики по поводу ареста от МИД Китая в сторону посла США прозвучало: «Действия США крайне омерзительны» [Американского посла... 2018]. В качестве асимметричной реакции на действия властей Канады китайцы задержали в Пекине двух канадцев по подозрению в действиях по подрыву национальной безопасности КНР. Также в Китае был задержан старший советник по Юго-Восточной Азии Майкл Ковриг [Сидорчик 2018].

Добавился еще один аспект противостояния гигантов, на этот раз валютный. Так, «Нью-Йорк Таймс» (The NewYork Times) писала: «Торговая война между Соединенными Штатами и Китаем вступила в более опасную фазу в понедельник, поскольку Пекин позволил себе ослабить курс своей валюты, китайские предприятия прекратили делать новые закупки американских сельскохозяйственных товаров, а казначейство президента Трампа официально признало Китай манипулятором валюты» [Swanson, Stevenson, Smialek, 2019]. 
От взаимных ударов стороны перешли к переговорам и к осени 2019 г. даже прошли первую фазу противостояния, т.е. заложили некие правила для урегулирования торговых споров. Китай, то ли выигрывая время перед основной битвой, к которой сейчас он оказался не готов, то ли желая достичь хотя бы почетных условий капитуляции, шел на уступки, постепенно сдавая защищаемые рубежи.

Соломинкой, которая сломала спину верблюда, оказалась трагедия с коронавирусом, ставшая новостью № 1. Блогосфера наполнена конспирологическими теориями о том, что коронавирус имеет не только искусственное происхождение, но и конкретное авторство, ибо слишком вовремя для США возник этот фактор, сломавший сопротивление Поднебесной. Обсуждаемый тезис о том, что вирус поражает в основном представителей азиатской расы, подводит к мысли о принципиальной возможности создания на базе современной науки так называемого «этнического оружия». Кстати, и в Штатах не стесняются обсуждать, что образовавшиеся из-за трагедии потери Китая выгодны для развития бизнес-проектов США.

Поражение КНР в торговой войне юридически оформлено в январе 2020 г. в виде «исторического соглашения», согласно которому Китай «принужден к миру». В нарушение принципов ВТО и вообще свободной торговли Поднебесная в порядке капитуляции должна закупить товаров, произведенных в США, на сумму около 200 млрд долл. за следующие два года. Кроме того, проигравшая сторона в одностороннем порядке и в интересах США должна провести реформы в ряде ключевых отраслей экономики.

Трамп объявил о своей победе в торговой войне. Однако системные противоречия между восходящей страной и страной, которая теряет свои позиции, никуда не делись [Межгосударственные отношения 2015]. Пекин обещал подумать об этом после того, как справится со вспышкой коронавируса. Интрига в том, даст ли Вашингтон Пекину время на восстановление позиций и обдумывание.

Растет напряжение в приграничных спорах Китая. Так, китайцы претендуют на 90\% акватории Южно-Китайского моря, ссылаясь на так называемую «девятипунктирную линию». С помощью этих пунктиров Пекин (в частном порядке в 1948 г., на государственном уровне в 1953 г.) самостоятельно, ни с кем не согласовывая, очертил «зону своих национальных интересов» в Южно-Китайском море от континентального Китая и острова Хайнань до берегов Брунея и Малайзии. С 1974 г. Китай фактически захватил Парасельские острова. Затем Пекин обратил внимание на архипелаг Спратли. С 2012 г. Китай контролирует риф Скарборо в Южно-Китайском море. Кроме того, КНР укрепляет свои позиции, насыпая искусственные острова. Непосредственно это не затрагивает территориальные интересы Соединенных Штатов, но большая часть стран, с кем Китай вступает в конфликт в регионе, являются 
союзниками США. Будут ли США защищать интересы Филиппин, Вьетнама, Малайзии или Брунея, неизвестно. Вопрос можно сформулировать иначе: посчитают ли в Вашингтоне выгодным для себя использовать этот фактор для сдерживания КНР? Приведем следующий пример. Так, фактический отказ США выступать на стороне своих союзников, каковыми для США длительное время на Ближнем Востоке являлись курды, в конфликте, когда другой союзник по НАТО - Турция, наступает, свидетельствует о том, что США в вопросах союзничества могут выступать настолько гибко, что и говорить о реальном союзничестве достаточно сложно. Однако регион, где проходит до $40 \%$ мирового морского трафика, не может оказаться вне интересов США. При этом Вашингтон ссылается на решения международного арбитража $\mathrm{OOH}$, запрещающего Китаю экспансию в регионе. Тогда как Пекин отвечает, что не признает права третьих лиц решать судьбу национальных интересов страны. О том, что обстановка обостряется и возможны форс-мажорные ситуации с тяжелыми последствиями, пишет «Ньюсуик» (Newsweek). Так, peaгируя на то, какими методами Штаты пытаются вытеснить КНР из региона, Чжан Цзюньшэ, сотрудник Военно-морского исследовательского института НОАК, заявил журналистам, что в случае столкновения судов или вспышки агрессии в результате провокации или ошибки, китайская сторона возлагает всю ответственность на США [Maza 2019].

Общий геополитический тренд XXI в. все больше сводится к конфликту между США и КНР. Соединенные Штаты расценивают свое глобальное лидерство как единственно возможный формат развития человечества. Иные точки зрения заранее объявляются ложными и вредными. Конечно, для достижения своих истинных целей еще используются наработанные в эпоху зыбкого равновесия Востока и Запада понятия: «свобода», «рынок», «права человека», «демократия».

Однако отбрасывая флер отвлекающих деклараций, необходимо выделить главное содержание реальной политики Вашингтона при любой администрации: Штатам нужно либо доминирование по типу «сюзерен - вассал», либо они объявляют страну «врагом свободного мира» и стараются ее всеми силами уничтожить. Однако Китай в XXI в. не согласен ни на первое, ни на второе. Чем сильнее Поднебесная, тем сложнее ей навязывать чужую волю.

Рассмотрим некоторые примеры напряженности, исходящей из Вашингтона.

1. Известно, что США обладают спорной договороспособностью. Это обусловлено присущей им позицией давления и принижения контрагента вместо равного диалога с ним. Выкручивание рук - это фирменный стиль, используя который заокеанские дипломаты общаются не только с соперниками на мировой арене, но и со своими ближайшими сателлитами. Штаты вышли из ряда долгосрочных соглашений (договор об ограничении РСМД, 
«сделка по Ирану», договор об ограничении систем ПРО, международное соглашение по Тихоокеанскому партнерству и др.). Договор о НАФТА (USMCA) с Канадой и Мексикой подписан в 2018 г. в атмосфере давления и ультиматумов на условиях более широкой экспансии товаров США. Презентованная Трампом «Сделка века» 2020 г. по палестинской проблеме представляется сговором между США и Израилем, проводимым без участия самих палестинцев и вопреки их интересам. При этом даже при заключении более-менее приемлемых договоров любые контрагенты должны быть заранее готовы к тому, что каждая новая администрация способна от них отказаться. Отсюда вывод: с Белым Домом нет смысла о чем-то договариваться на длительный срок. Капитуляция Китая в торговой войне с США от января 2020 г. принята не на основе сотрудничества и взаимной выгоды, а под влиянием ультимативного требования.

2. Военное преимущество больше не является решающим фактором. Несмотря на колоссальные суммы, которые США тратят на вооружения и содержание имеющейся военной машины, подавляющего доминирования в политике они не имеют. Мощь, которую нельзя применить, не имеет смысла. Так, прямое применение военной силы по отношению к Китаю неизбежно ведет к мировой войне с применением оружия массового поражения. В войне, которая приведет цивилизацию к гибели, не будет победителей. Поскольку США пока не могут безнаказанно использовать крайние средства по отношению к Китаю, локальные битвы между двумя странами ведутся на других площадках: торговых, информационных, политических, технологических и т.д.

3. США предпочитают вести международные дела только в обстановке преимуществ со своей стороны и уступок со стороны контрагентов. И хотя экономическая мощь Китая еще не конвертировалась в политическое влияние, тем не менее диктовать условия Китаю все сложнее. Это видно и по общей атмосфере двусторонних контактов, и по общению в рамках международных институтов. Возможность одного из членов организации сопротивляться давлению гегемона влияет на общую атмосферу внутри международного института. Китай научился использовать правила международных организаций, и это не устраивает силы, ранее диктовавшие условия общения в рамках этих форматов. Немудрено, что организации, которые не удовлетворяют претензии США на превосходство, становятся им неинтересны (ВТО, ООН и т.д.) [Трамп заявил... 2018].

4. Курс на предоставление исключительных преимуществ только американским компаниям неизбежно ведет к экономической, а вслед за ней политической и военной конфронтациям.

5. В условиях информационного глобализма контроль над мировыми СМИ уже не гарантирует монополию на информацию и ее интерпретацию. США все труднее подавлять иную точку зрения на свои действия. В мире 
растет число недовольных «однополярным» мировым порядком и тем, как Штаты ведут дела в мире. Так, уровень одобрения американской политики жителями других стран при администрации Трампа достиг исторического минимума [Трамп добился... 2018].

6. Монополия доллара не удовлетворяет национальным интересам других стран. На повестке дня ситуация, когда мировые игроки могут отказаться от доллара и перестанут поддерживать своими ресурсами выплату государственных долгов США. Утрата доминирующих позиций «вечнозеленой валюты» неизбежно скажется на экономике Штатов, и Вашингтон всеми силами готов препятствовать такому развитию событий. Однако если маленькую Ливию удалось отговорить от попытки отказаться от доллара и установить золотой динар в 2011 г., не факт, что подобный сценарий применим к наращивающему свою мощь Китаю. Пекин заинтересован в том, чтобы юань стал третьей резервной валютой мира (вслед за долларом и евро). Двигаясь по пути дедолларизации, Россия и Китай заключили в 2019 г. соглашение о переходе во взаиморасчетах на национальные валюты [Доллар исключен... 2019].

7. США теряют технологическое преимущество. Так, Россия опередила другие страны в создании гиперзвукового оружия, а Китай первым создал технологию $5 \mathrm{G}$.

8. США пытаются распространить действие своего законодательства на другие страны. Однако не все государства готовы подпадать под юрисдикцию американских судов. К числу стран, не готовых подчиняться решениям заокеанской Фемиды, относятся и Китай, и Россия. В связи с этим символично, что именно сейчас обсуждаются предложенные Президентом России В. Путиным поправки в наш Основной закон. В озвученном контексте представляет интерес предложение убрать из Конституции России п. 4 ст. 15, в котором говорится о включении в правовую систему неких «общепризнанных принципов и норм международного права» и даже о примате их над внутренним законодательством, поскольку при существующем контроле над глобальными СМИ формула «общепризнанные» может восприниматься как «признанные Штатами».

9. США в мировых вопросах, будь то экономика, политика или климат, часто занимают деструктивную позицию, которая ущемляет интересы других стран. Так, действуя по принципу «Америка превыше всего», Д. Трамп заявил о выходе США из Парижского соглашения по климату, тогда как именно США производят наибольшую массу выбросов парниковых газов в атмосферу планеты.

10. США уже не в состоянии заплатить или аннулировать свои долги Китаю - речь может идти о прямом конфликте. Возможно, именно эта сторона вопроса перевесит все другие причины, ведь, как известно, «война все спишет». Опасность развивающейся ситуации в том, что современная наука 


\section{РОССИЯ И МИР В ХХІ ВЕКЕ}

способна подготовить новейшие формы нападения, будь то хакерская атака или заражение населения страны-противника вирусом. Человечество может и не осознать, что первый выстрел этой необъявленной войны уже прозвучал.

11. Убийство Касема Сулеймани 3 января 2020 г., осуществленное без какого-либо информационного прикрытия, показало, что США исповедуют в международных отношениях политику «государственного терроризма». Всему миру стало ясно, что Соединенные Штаты не будут придерживаться норм международного права и даже минимальных правил приличия.

Таким образом, перечисленных факторов уже достаточно, чтобы понять, что США не готовы смириться с падением своего влияния в мире. Поскольку рост экономической мощи и политического влияния Поднебесной угрожает национальным интересам США (во всяком случае, так понимают ситуацию в Вашингтоне), реальная конфронтация видится неизбежной. Подбор средств нападения и сдерживания происходит независимо от того, что произносится публично, о чем заявляют политики и пишут политологи. Сейчас где-то в тиши кабинетов происходит мучительный выбор «где и когда» состоится решающее сражение. Впереди будут и тактические отступления, и похлопывания по плечу, и совместные культурные программы. США будут заявлять о своей исторической миссии продвижения демократии и защиты свободы. В свою очередь, лидеры Китая подтвердят курс на мирное развитие экономики и сотрудничество со всеми желающими торговать. Однако приоритет национальных интересов над соображениями коллективного строительства мира, безопасного и комфортного для всех, довлеет над ситуацией и, по пессимистическим оценкам, уже не позволяет избежать грядущей битвы гигантов. Лозунги «Америка превыше всего» или «Китай превыше всего» ведут к войне. К миру могли бы привести лозунги «Человечество превыше Америки» и «Человечество превыше Китая». Но способны ли две сверхдержавы отказаться от эгоистичных путей развития в пользу общемирового спасения?

Было бы неправильным воспринимать это движение к войне только «достижением» политики США. Китай также идет навстречу сражению исходя из логики поступательного развития.

Рассмотрим некоторые встречные «пунктирные линии», из-за которых Китай также движется к реальному конфликту с США в XXI в.

1. Период, когда Китай мог развиваться, не затрагивая серьезно интересы США, завершен. Рынки поделены, всякое расширение одной стороны влечет проигрыш другой. Это показала и «первая фаза» торговой сделки. Движение вперед, когда одна сторона приобретает выгоды, а другая при этом хотя бы ничего не теряет, стало невозможным.

2. Значительно выросла военная мощь КНР. Наращиваются компоненты ядерной триады. Согласно докладу Пентагона, в июне 2019 г. успешно испытана новейшая баллистическая ракета подводного базирования JL-3 (SLBM) 
с радиусом действия до 9000 км. Китай обладает баллистическими ракетами средней дальности от 80 до 160 (в 2018 г. соответствующий сегмент оценивался от 16 до 30 ракет), включая ядерные ракеты DF-26 с радиусом действия 4000 км, которые были впервые введены в эксплуатацию в 2016 г. [SandersZakre, Davenport 2019]. На параде Вооруженных сил КНР 1 октября 2019 г. Китай показал гиперзвуковые баллистические ракеты «Dongfeng-17», тем самым заявляя о своем лидерстве в этой отрасли. Строится современный флот. Китай уже создает авианосные группы, способные защищать морские коммуникации в регионе. За последние 20 лет расходы на оборону увеличились почти в 18 раз - с 10 млрд долл. до 177,6 млрд долл. В 2019 г. только Штаты превосходят КНР по размеру военных расходов. При этом следует учитывать, что реальные расходы могут быть значительно выше опубликованных, поскольку частично скрыты по гражданским статьям [Olsen 2019]. Шесть авианосцев, на каждом из которых размещено 20 истребителей-невидимок J-20, таковы ближайшие планы на постройку флота в дополнение к уже имеющимся кораблям [Ахе 2019].

КНР наращивает силу не только в обычном оружии, но и находится среди лидеров в разработке и производстве новейших видов. Это позволяет Пекину более жестко и принципиально заявлять о собственных национальных интеpecax.

3. Китай осуществил технологический рывок. Зависимость от американских технологий падает. Китай проектирует собственный гражданский самолет. Опережает в технологии 5 G. В качестве платы за доступ к своему рынку КНР перенимает западные технологии и считает это вполне справедливым [Wei, Davis 2018].

4. Поднебесная вышла на передовые рубежи в ряде отраслей экономики, опережая США.

5. Пекин способен отмобилизовать общество в случае эскалации конфликта с США. При этом консолидация внутри Поднебесной может сопровождаться и массовой поддержкой исторической родины со стороны китайской диаспоры в США.

6. Китай проводит глобальные инфраструктурные проекты вне подчинения и сферы контроля США.

7. Растет национальное самосознание китайцев, которые больше не готовы терпеть унижения со стороны «белых партнеров».

8. Огромный торговый трафик, тесный симбиоз в экономике привел к тому, что Пекин ощущает не только зависимость от США, но и собственное влияние на Штаты. В результате у китайцев имеются все основания требовать уважения к себе и своим национальным интересам. 


\section{РОССИЯ И МИР В ХХІ ВЕКЕ}

9. Китай не согласен с диктатом США в международных судах и организациях и будет требовать изменения правил игры. Если же исправить ситуацию будет невозможно, Китай может начать создавать параллельные структуры.

10. Пекин винит США во вмешательстве во внутренние дела, военной накачке Тайваня, дестабилизации Гонконга и Синьцзяна. В отличие от мифической «руки Москвы» в выборах президента США Китай вполне способен реально включить имеющиеся у него рычаги в деструктивные действия ответного плана.

11. Китай готов взять под контроль судоходство в Южно-Китайском море и защищать свои морские коммуникации всей мощью своего ВМФ.

12. В связи с повышением благосостояния китайцев растет емкость внутреннего рынка, в результате зависимость от экспорта товаров в США будет снижаться. В результате возрастет свобода маневра в отношениях и возможность проведения более жесткой позиции по принципиальным вопросам.

Таким образом, Китай также движется к конфликту с США по объективным и субъективным причинам. Предыдущая китайская внешняя политика по «умиротворению агрессора» являлась лишь тактической уступкой и выигрыванием времени на модернизацию и подготовку к фазе реальной борьбы. Психологическая разница между идейными установками КНР и США в будущем конфликте представляется следующим образом: если Штаты будут бороться за мировое господство и свою главенствующую роль в мире, то КНР будут сражаться за собственное выживание перед лицом опасного и беспощадного противника.

Эксперты все чаще вспоминают «ловушку Фукидида»: мощь Афин росла, u Cnарта начала беспокоиться [Farley 2019]. Что же беспокоит аналитиков в США? Если в 1980 г. ВВП КНР составлял 10\% от ВВП США, измеряемого по паритету покупательной способности, 7\% ВВП по текущему курсу доллара США и 6\% его экспорта, то к 2014 г. эти цифры составляли $101 \%$ ВВП, $60 \%$ по курсу доллара США и 106\% экспорта. Запасы Китая сегодня в 28 раз больше, чем у Америки. И все это произошло на глазах у одного поколения. Американские политологи и экономисты в панике, поскольку лидерство США оказалось под угрозой [Olsen 2019]. Претворение в жизнь судьбоносных планов модернизации страны, озвученных на XIX Всекитайском съезде компартии, представляет угрозу национальным интересам Соединенных Штатов, не готовых мириться с укреплением соперника.

В США считают, что если в общемировом масштабе они сильнее Китая, то в своем регионе, а под таковым подразумевается не только Южно-Китайское море, но и вся Юго-Восточная Азия, конкурировать с Поднебесной все сложнее [Wei, Davis 2018]. В поисках противовеса растущему Китаю в Индийском океане Штаты одно время пытались поставить на Индию, создавая с ней так называемый «стратегический диалог» [Межгосударственные отно- 
шения... 2015]. Однако обострение отношений между Китаем и США поставило Индию перед выбором - дружить с обеими сторонами уже не получится [Косырев 2019].

Поскольку петля конфликта затягивается, имеет смысл хотя бы в общих чертах задуматься, когда именно вероятна кульминация в противостоянии.

Несмотря на резкую антикитайскую полемику Трампа, после капитуляции Пекина в торговой войне дальнейшее обострение конфликта в период до 2024 г. представляется маловероятным. Все-таки Дональд Трамп ни одной «горячей» войны еще не начал, и судя по его риторике и действиям, подчас хаотичным, он будет продолжать колебание вокруг оси торговых и таможенных войн. После Трампа существует вероятность того, что внутренние распри в США приведут к смене президента по «майданным технологиям», опробованным на Украине в 2014 г.

После «времени хаоса» предполагается приход «сильной руки», наводящей порядок. Именно в этот период возможно наиболее острое противостояние с КНР, поскольку концентрация жесткой власти в самих Штатах неизбежно приведет и к попыткам восстановления монополии на власть в мире. Произойдет это в 2066 г., как прописано в сценарии «Fallout», или раньше, предсказывать сложно - все зависит от того, насколько затянется «период хаоса» в «разъединенных» к тому времени Штатах. Не исключено, что обострение противоборства сверхдержав, с учетом того что обе страны обладают ядерным оружием, а значит - прямой обмен ударами не оставит победителей, будет протекать по сирийскому сценарию, когда военные базы могут быть атакованы беспилотниками, обе стороны будут догадываться, кто ими управляет, но официально будет считаться, что акцию проводят неизвестные боевики. Для нанесения сокрушительных ударов могут быть использованы хакерские атаки, новые губительные вирусы, климатические диверсии, еще не опробованные технологии двойного применения. Главное, что современное информационное общество позволяет атаковать анонимно и безнаказанно. Соблазн для правящих элит США сохранить статус-кво с помощью самых разнообразных средств, имеющих характер войны, но не приводящих к ядерным бомбардировкам, с продвижением новых научных разработок будет возрастать.

С другой стороны, Пекин намерен полностью модернизировать экономику до 2035 г., а к 2049 г. стать мировым лидером (что подтекстом звучит в решениях XIX съезда КПК под рубрикой «стать государством с высоким развитием и уровнем доходов»). Фактически вопрос, сформулированный в виде «успеет ли Китай модернизировать экономику?», в первоначальном варианте может звучать так: «Успеет ли Китай модернизировать экономику до войны c США?» [Успеет ли Китай... 2018]. 
Следовательно, чем позднее США перейдут от торговых и санкционных войн к войне локальной или полноценной, тем меньше у них шансов остановить Поднебесную. Как вариант, может быть использована марионеточная сила, которая будет атаковать КНР при поддержке США. Будет ли это движение называться «армия освобождения Тибета», «захвати Гонконг» или «свободу Синьцзяну», покажет время. Также не исключен встречный вариант, когда при ослаблении центральной власти в Вашингтоне Китай попробует вернуть находящийся под протекторатом США Тайвань. Так или иначе, системные причины, ведущие две страны к войне, сами по себе не исчезнут. В XXI в. прямой конфликт США и Китая обретает новые контуры.

Чтобы представить себе остроту проблемы, стоит отметить ряд фоновых факторов, также влияющих на скорость обострения конфликта.

1. В XXI в. усиливается конкуренция и борьба за ресурсы планеты. При этом ресурсами являются не только минерально-сырьевые (нефть, газ, лес и т.д.), но и транспортные коммуникации (Северный морской путь, «Морской шёлковый путь XXI века»), доступ к информации, чистый воздух, экологически и генетически чистое продовольствие, пресная вода и др. Отсутствие справедливого регулирования в распределении ресурсов ведет к войне. Интересы США и Китая в этом процессе диаметрально противоположны.

2. Появились новые площадки для столкновения, где нет никаких правил и договоренностей, например Интернет. От урегулирования проблемы на международном уровне страны, и в первую очередь США, продолжают уклоняться. Китай также вынужден защищаться в этих виртуальных сражениях. Эскалация напряженности в Сети влияет на общую атмосферу международного общения.

3. Гонка вооружений в новейших областях бесконтрольна. Отсутствие гарантий безопасности заставляет ради сохранения суверенитета идти на беспрецедентные меры (например, Северная Корея вынуждена вооружаться, несмотря на падение уровня жизни населения). Новые технологии в области вооружений ведут к тому, что любой локальный конфликт может вести к глобальным последствиям.

4. Международное право не действует. В результате деструктивной политики США нарастает хаос в мировых делах. Организация Объединенных Наций в глубоком кризисе, поскольку страны-основательницы уже не способны поддерживать мировой порядок. И хотя Президент России В. Путин обратился к постоянным членам Совета Безопасности ООН с предложением организовать встречу для оздоровления международной обстановки, англосаксонские партнеры (США и Великобритания) не спешат позитивно откликаться на этот призыв [Бовдунов, Комарова 2020]. Культ «силы» в международных отношениях, вызванный действиями США и других стран Запада, также ведет к войне. 
5. Глобальные проблемы, стоящие перед человечеством, решать некому, поскольку национальный эгоизм ведущих стран мира ведет к общему упадку цивилизации.

Конфликт между США и Китаем имеет системный характер. По своему разрушительному потенциалу в стратегической перспективе он способен превзойти конфликт между США и Россией. Это противостояние обусловлено комплексом неразрешимых на современном этапе развития противоречий экономических, политических, идеологических и даже субъективных, т.е. основанных на личном восприятии ситуации лидерами элит и руководимыми ими народами. Каждая из стран имеет собственные установки на оттягивание или приближение развязки. В результате нарастания напряженности между Китаем и США вероятность реализации одного из сценариев массированного конфликта, наподобие описанного создателями упомянутой игры «Fallout», продолжает увеличиваться. Экспертное сообщество все чаще задается вопросом не о том, будет ли война между Китаем и США, а о том, когда состоится неизбежная «битва за Анкоридж».

\section{Библиография}

Американского посла вызвали в МИД Китая // Война и мир. 2018. 09 янв. URL: https://www.warandpeace.ru/ru/news/view/135809/ (дата обращения: 19.01.2020).

Бовдунов А., Комарова Е. «Прорывная инициатива»: как предложенный Путиным саммит постоянных членов СБ ООН может повлиять на ситуацию в мире // RT на русском. 2020. 25 янв. URL: https://russian.rt.com/world/article/711355-putin-sovbez-oon-sammit-reakciya (дата обращения: 11.02.2020).

Доллар исключен из расчетов между Россией и Китаем // EurAsiaDaily. 2019. 28 июня. URL: https://eadaily.com/ru/news/2019/06/28/dollar-isklyuchyon-iz-raschyotov-mezhdu-rossiey-ikitaem (дата обращения: 11.02.2020).

Косырев Д. Не быть съеденной гигантами: Индия хотела дружить с США и Китаем. Не вышло // РИА Новости. 2019. 16 июля. URL: https://ria.ru/20190716/1556569337.html (дата обращения: 19.01.2020).

Межгосударственные отношения США и Индии // РИА Новости. 2015. 25 янв. URL: https://ria.ru/20150125/1043979115.html (дата обращения: 19.01.2020).

Сидорчик А. Ответил за Нuаwei? Китай арестовал экс-дипломата Канады // Аргументы и факты. 2018. 12 дек. URL: https://aif.ru/politics/world/otvetil_za_huawei_kitay_arestoval_eksdiplomata_kanady (дата обращения: 19.01.2020).

Суслов Д. Почему победить Трампа в 2020-м будет непросто // Независимая. 2019. 29 июля. URL: https://yandex.ru/turbo/s/ng.ru/kartblansh/2019-07-29/3_7635_kartblansh.html (дата обращения: 19.01.2020).

Трамп добился рекордной ненависти к США // Взгляд. Рамблер / Новости. 2018. 19 янв. URL: https://news.rambler.ru/world/38933109-tramp-dobilsya-rekordnoy-nenavisti-k-ssha/ (дата обращения: 10.02.2020).

Трамп заявил о возможном выходе США из ВТО // РИА Новости. 2018. 31 авг. URL: https://ria.ru/20180831/1527553332.html (дата обращения: 19.01.2020).

Успеет ли Китай модернизировать экономику? // BECTИ. ru. 2018. 16 февр. URL: https:// www.vesti.ru/doc.html?id=2988059\&cid=6 (дата обращения: 19.01.2020). 


\section{РОССИЯ И МИР В ХХІ ВЕКЕ}

Axe D. China Wants a 6 Carrier Navy with J-20 Stealth Fighters // The National Interest. 2019. 09 Okt. URL: https://nationalinterest.org/blog/buzz/china-wants-6-carrier-navy-j-20-stealth-fighters86746 (дата обращения: 19.01.2020).

Farley R. A 2030 War Between America and China Would Shake the World // The National Interest. 2019. 06 Sept. URL: https://nationalinterest.org/blog/buzz/2030-war-between-america-andchina-would-shake-world-78771(дата обращения: 19.01.2020).

Maza C.U.S. - China military conflict in south china sea would be Washington's fault, Chinese expert claims // Newsweek. 2019. 09 Jan. URL: https://www.newsweek.com/us-china-militaryconflict-south-sea-1285521 (дата обращения: 22.02.2020).

Olsen K. China's defense spending is growing more slowly. But that doesn't mean military tensions are easing // CNBS 2019. 05 May. URL: https://www.cnbc.com/2019/03/05/china-defensebudget-slowing-growth-in-2019-military-spending-.html (дата обращения: 19.01.2020).

Sanders-Zakre A., Davenport K. Pentagon Warns of Chinese Nuclear Strength // Arms Control Association July. 2019. July / August. URL: https://www.armscontrol.org/act/2019-07/news/pentagon-warns-chinese-nuclear-strength (дата обращения: 22.01.2020).

Swanson A., Stevenson A., Smialek J. China's Currency Moves Escalate Trade War, Rattling Markets // The New York Times. 2019. 05 Aug. URL: https://www.nytimes.com/2019/08/05/ business/economy/us-china-yuan-renminbi-trump.html (дата обращения: 19.01.2020).

Trump acquitted by Senate in impeachment trial // BBS News. 2020. 06 Feb. URL: https:// www.bbc.com/news/world-us-canada-51394383 (дата обращения: 22.02.2020).

Wei L., Davis B. How China systematically pries technology from U.S. companies // The Wall Street Journal. 2018. 26 Sept. URL: https://www.wsj.com/articles/how-china-systematically-priestechnology-from-u-s-companies-1537972066 (дата обращения: 22.01.2020).

\section{References}

Amerikanskogo posla vy`zvali v MID Kitaya [The American ambassador was summoned to the Ministry of Foreign Affairs of China]. War and Peace. 2018. Jan. 09. URL: https://www.warandpeace.ru/ru/news/view/135809/ (date of access: 01.19.2020). (In Russ.)

Axe D. China Wants a 6 Carrier Navy with J-20 Stealth Fighters. The National Interest. 2019. 09 Okt. URL: https://nationalinterest.org/blog/buzz/china-wants-6-carrier-navy-j-20-stealth-fighters86746 (date of access: 19.01.2020).

Bovdunov A., Komarova E. «Prory`vnayainiciativa»: kak predlozhenny `jPutiny`m sammit postoyanny`x chlenov SB OON mozhet povliyat' na situaciyu v mire [«Breakthrough initiative»: how Putin's summit of permanent members of the UN Security Council proposed by Putin can affect the situation in the world]. RT in Russian 2020. Jan. 25. URL: https://russian.rt.com/world/article/ 711355-putin-sovbez-oon-sammit-reakciya (date of access: 02.11.2020). (In Russ.)

Dollar isklyuchyon iz raschyotov mezhdu Rossiej i Kitaem [The dollar is excluded from the calculations between Russia and China]. EurAsia Daily. 2019. June 28. URL: https://eadaily.com/en/ news/2019/06/28/dollar-isklyuchyon-iz-raschyotov-mezhdu-rossiey-i-kitaem (date of access: 11.02. 2020). (In Russ.)

Farley R. A 2030 War Between America and China Would Shake the World // The National Interest. 2019. 06 Sept. URL: https://nationalinterest.org/blog/buzz/2030-war-between-america-andchina-would-shake-world-78771 (date of access: 19.01.2020).

Kosy`rev D. Ne by 't’ s “edennoj gigantami: Indiya xotela druzhit`s SShA i Kitaem. Ne vy`shlo [Not to be eaten by giants: India wanted to be friends with the USA and China. It did not work out]. RIA Novosti. 2019. July 16. URL: https://ria.ru/20190716/1556569337.html (date of access: 01.19.2020). (In Russ.) 
Maza C.U.S. - China military conflict in south china sea would be Washington's fault, Chinese expert claims // Newsweek. 2019. 09 JAN. URL: https://www.newsweek.com/us-china-militaryconflict-south-sea-1285521 (date of access: 22.02.2020).

Mezhgosudarstvenny`e otnosheniya SShA I Indii [Interstate relations of the USA and India]. RIA Novosti. 2015. Jan 25. URL: https://ria.ru/20150125/1043979115.html (date of access: 01.19.2020). (In Russ.)

Olsen K. China's defense spending is growing more slowly. But that doesn't mean military tensions are easing // CNBS 2019. 05 May. URL: https://www.cnbc.com/2019/03/05/china-defensebudget-slowing-growth-in-2019-military-spending-.html (date of access: 19.01.2020).

Sanders-Zakre A., Davenport K. Pentagon Warns of Chinese Nuclear Strength // Arms Control Association July. 2019. July / August. URL: https://www.armscontrol.org/act/2019-07/news/pentagon-warns-chinese-nuclear-strength (date of access: 22.01.2020).

Sidorchik A. Otvetil za Huawei? Kitaj arestoval e'ks-diplomata Kanady' [Answered for Huawei? China arrested ex-diplomat of Canada]. Arguments and Facts. 2018. Dec 12. URL: https://aif.ru/politics/world/otvetil_za_huawei_kitay_arestoval_eks-diplomata_kanady (date of access: 01.19.2020). (In Russ.)

Suslov D. Pochemu pobedit' Trampa v 2020-m budet neprosto [Suslov D. Why defeating Trump in 2020 will not be easy]. Independent. 2019. July 29. URL: https://yandex.ru/turbo/s/ng.ru/ kartblansh/2019-07-29/3_7635_kartblansh.html (date of access: 01.19.2020). (In Russ.)

Swanson A., Stevenson A., Smialek J. China's Currency Moves Escalate Trade War, Rattling Markets // The New York Times. 2019. 05 Aug. URL: https://www.nytimes.com/2019/08/05/business/ economy/us-china-yuan-renminbi-trump.html (date of access: 19.01.2020).

Tramp dobilsya rekordno jnenavisti k SShA [Trump has achieved record hatred of the United States]. Business newspaper «Vzglyad». Rambler/ News. 2018. Jan. 19. URL: https://news.rambler. ru/world/38933109-tramp-dobilsya-rekordnoy-nenavisti-k-ssha/ (date of access: 10.02.2020). (In Russ.)

Tramp zayavil o vozmozhnom vy`xode SShA iz VTO [Trump announced the possible US withdrawal from the WTO]. RIA Novosti. 2018. Aug. 31. URL: https://ria.ru/20180831/ 1527553332.html (date of access: 01.19.2020). (In Russ.)

Trump acquitted by Senate in impeachment trial // BBS News. 2020. 06 Feb. URL: https:// www.bbc.com/news/world-us-canada-51394383 (date of access: 22.02.2020).

Uspeet li Kitaj modernizirovat’ e'konomiku? [Will China manage to modernize the economy?]. VESTI. ru. 2018. Feb. 16. URL: https://www.vesti.ru/doc.html?id=2988059\&cid=6 (date of access: 01.19.2020). (In Russ.)

Wei L., Davis B. How China systematically pries technology from U.S. companies. The Wall Street Journal. 2018. 26 Sept. URL: https://www.wsj.com/articles/how-china-systematically-priestechnology-from-u-s-companies-1537972066 (date of access: 22.01.2020). 